\title{
PENGARUH DOSIS BATUAN FOSFAT ALAM (BFA) YANG TELAH DIASIDULASI DENGAN LIMBAH CAIR TAHU TERHADAP PERTUMBUHAN DAN PRODUKSI TANAMAN KEDELAI (Glycine max L.)
}

\author{
Sunyoto $^{1)}$, Garcia Rahmadita ${ }^{2)}$, Sri Yusnaini' ${ }^{1)}$, Kuswanta Futas Hidayat ${ }^{1)}$ \\ ${ }^{1}$ Dosen Jurusan Agroteknologi, Fakultas Pertanian, Universitas Lampung \\ ${ }^{2}$ Mahasiswa Jurusan Agroteknologi, Fakultas Pertanian, Universitas Lampung \\ Jl. Prof. Dr. Sumantri Brojonegoro No. 1, Bandar Lampung 35145
}

\begin{abstract}
ABSTRAK
Penelitian ini bertujuan untuk mengetahui pengaruh dan dosis terbaik dari batuan fosfat alam (BFA) yang diasidulasi limbah cair tahu yang dalam meningkatkan pertumbuhan dan produksi tanaman kedelai (Glycine max L.). Penelitian dilakukan di Balai Pengkajian Teknologi Pertanian (BPTP) Unit Kebun Percobaan Natar Kabupaten Lampung Selatan dan Laboratorium Fakultas Pertanian Universitas Lampung pada Mei hingga September 2017. Penelitian dilakukan dengan menggunakan Rancangan Acak Kelompok (RAK) dengan 7 perlakuan dan 3 ulangan. Perlakuan yang diberikan meliputi : $\mathrm{P}_{0}=$ tanpa Batuan Fosfat Alam (BFA), $\mathrm{P}_{1}=\mathrm{BFA} 300 \mathrm{~kg} \mathrm{ha}^{-1}$ (tanpa asidulasi), $\mathrm{P}_{2}=$ BFA $150 \mathrm{~kg} \mathrm{ha}^{-1}$ (diasidulasi dengan limbah tahu), $\mathrm{P}_{3}=\mathrm{BFA} 300 \mathrm{~kg} \mathrm{ha}^{-1}$ (diasidulasi dengan limbah tahu), $\mathrm{P}_{4}=$ BFA $450 \mathrm{~kg} \mathrm{ha}^{-1}$ (diasidulasi dengan limbah tahu), $\mathrm{P}_{5}=\mathrm{BFA} 600 \mathrm{~kg} \mathrm{ha}^{-1}$ (diasidulasi dengan limbah tahu), dan $\mathrm{P}_{6}=$ BFA $750 \mathrm{~kg} \mathrm{ha}^{-1}$ (diasidulasi dengan limbah tahu). Hasil penelitian menunjukkan bahwa pemberian BFA yang telah diasidulasi dengan menggunakan limbah cair tahu dapat meningkatkan bobot brangkasan kering dibandingkan dengan BFA yang tidak diasidulasi limbah cair tahu. Pemberian BFA yang diasidulasi limbah cair tahu dengan dosis $600 \mathrm{~kg} \mathrm{ha}^{-1}$ dan $750 \mathrm{~kg} \mathrm{ha}^{-1}$ mampu memberikan bobot brangkasan kering sebesar 3,28 gram petak $^{-1}$ dan sebesar 3,14 gram petak $^{-1}$.
\end{abstract}

Kata kunci: asidulasi, batuan fosfat alam (BFA), kedelai.

\section{PENDAHULUAN}

Kedelai merupakan salah satu komoditas yang banyak digemari oleh masyarakat Indonesia. Kedelai dapat diolah menjadi bahan makanan seperti tempe, tahu, kecap, susu, serta dapat digunakan sebagai bahan baku industri, bahan penyegar, maupun untuk pakan ternak. Oleh sebab itu, tanaman ini menjadi salah satu bahan pangan alternatif ke tiga setelah jagung dan gandum. Sebagai salah satu bahan pangan altenatif yang diminati oleh masyarakat, dampak penggunaan kedelai pun ikut tinggi,sehingga berpengaruhterhadap permintaan yang tinggi pula. Namun akibat tingginya permintaan tersebut tidak didukung dengan adanya peningkatan produksi yang signifikan. Rendahnya 
produksi kedelai di Indonesia salah satunya disebabkan oleh kondisi tanah yang kurang subur sehingga mengakibatkan tanaman kekurangan unsur hara untuk memenuhi kebutuhannya. Produksi kedelai di Indonesia selama ini cenderung fluktuatif. Berdasarkan data Kementan, rata-rata produksi biji kering kedelai nasional pada tahun 2014 “ 2018 sudah mengalami kenaikan meskipun sempat anjlok pada tahun 2017 yaitu sebesar 538.728 ton. Kemudian kembali meningkat pada tahun 2018 sebanyak 443.870 ton dari hasil produksi di tahun sebelumnya. Produksi tersebut diperoleh dari dari luasan panen sebesar 680.373 hektar dengan produktivitas sebanyak 1,4 ton $\mathrm{ha}^{-1}$. Meskipun telah mengalami peningkatan, produksi dan produktivitas kedelai tersebut masih tergolong rendah dan belum bisa memenuhi kebutuhan dalam negeri yang mencapai 2,4 juta ton, sehingga Indonesia masih harus mengimpor 1 juta ton biji kering untuk memenuhi kebutuhan kedelai nasional (Kementan, 2019).

Penyebab rendahnya produktivitas kedelai di Indonesia salah satunya disebabkan oleh rendahnya kualitas tanah sebagai medium tumbuh kedelai. Untuk memperbaiki masalah tersebut, satu upaya yang dapat dilakukan yaitu dengan memberikan unsur hara yang cukup bagi tanaman, diantaranya unsur fosfor. Penggunaan pupuk fosfat sebagai salah unsur yang memenuhi kebutuhan tanaman kedelai sangat diperlukan untuk memacu pertumbuhan akar dan pembentukan sistem perakaran serta memacu pertumbuhan generatif tanaman. Tetapi ketersediaan pupuk fosfat secara alamiah lambat tersedia sehingga menjadikan suatu permasalahan di kalangan petani, karena biasanya para petani hanya menggunakan pupuk-pupuk kimia karena mudah didapatkan walaupun harganya terbilang mahal dan dapat berdampak pada lingkungan jika digunakan secara terus menerus. Oleh karena itu untuk menggantikan penggunaan pupuk fosfat kimia digunakanlah pupuk Batuan Fosfat Alam (BFA). Akan tetapi penggunaan BFA tidak dapat diberikan langsung pada tanaman, melainkan harus melewati proses asidulasi (pemberian asam) terlebih dahulu agar kandungan P yang terjerap di dalam BFAdapat terlepas dan digunakan oleh tanaman. Penelitian ini bertujuan untuk mengetahui pengaruh dan dosis terbaik pada batuan fosfat alam (BFA) yang telah diasidulasi dengan limbah cair tahu dalam meningkatkan pertumbuhan dan produksi tanaman kedelai (Glycine max L.).

\section{METODE PENELITIAN}

Penelitian dilakukan di Balai Pengkajian Teknologi Pertanian (BPTP) Unit Kebun Percobaan Natar, Desa Negara Ratu, Kecamatan Natar, Kabupaten Lampung Selatan dan di Laboratorium Fakultas Pertanian, Universitas Lampung pada Mei sampai September 2017, menggunakan Rancangan Acak Kelompok (RAK) dengan 7 perlakuan dan 3 ulangan. Perlakuan yang diterapkan dalam penelitian ini yaitu $\mathrm{P}_{0}=\operatorname{tanpa}$ Batuan Fosfat Alam (BFA), $\mathrm{P}_{1}=$ BFA $300 \mathrm{~kg} \mathrm{ha}^{-1}$ (tanpa asidulasi), $\mathrm{P}_{2}=$ BFA $150 \mathrm{~kg}$ ha $^{-1}, \mathrm{P}_{3}=$ BFA $300 \mathrm{~kg} \mathrm{ha}^{-1}, \mathrm{P}_{4}=$ BFA $450 \mathrm{~kg} \mathrm{ha}^{-1}, \mathrm{P}_{5}$ $=$ BFA $600 \mathrm{~kg} \mathrm{ha}^{-1}, \mathrm{P}_{6}=$ BFA $750 \mathrm{~kg} \mathrm{ha}^{-1}$ (pada perlakuan $\mathrm{P}_{2}, \mathrm{P}_{3}, \mathrm{P}_{4}, \mathrm{P}_{5}$, dan $\mathrm{P}_{6}$, BFA diasidulasi terlebih dahulu dengan menggunakan limbah cair tahu). 
Data yang diperoleh diuji Bartlett untuk mengetahui homogenitas ragam dan Uji Tukey untuk mengetahui adivitas data. Jika asumsi terpenuhi, maka data dianalisisragam dan dilanjutkan dengan uji BNT 5\% untuk mengetahui perbedaan antarperlakuan, serta dilakukan uji korelasi antara sifat kimia tanah dengan tanaman kedelai.

Asidulasi BFAdengan limbah cair tahu dilakukan dengan cara mencampurkan limbah cair tahu dalam keadaan segar yang telah diinkubasi selama 5"7 hari hingga mencapai $\mathrm{pH}$ terendah dengan BFA, kemudian diinkubasi dengan perbandingan $1: 2$. Selanjutnya dilakukan pengadukan secara manual selama 7 hari. Setelah itu, dijemur untuk proses pengeringan. Setelah diperoleh BFA yang sudah kering, BFA dihaluskan dengan mesin penggiling dan diayak lalu ditimbang sesuai perlakuan. Batuan fosfat yang telah diasidulasi dianalisis untuk mengetahui kandungan P-larut (asam sitrat 2\%), dan P-total ( $\mathrm{HCl} 25 \%)$.

Tanaman kedelai ditanam pada lahan berukuran $3 \mathrm{~m} \times 3 \mathrm{~m}$ dengan jarak tanam $30 \mathrm{~cm} \times 30 \mathrm{~cm}$. BFA yang telah diasidulasi limbah cair tahu diaplikasikan sebelum penanaman sesuai dengan dosis perlakuan. Aplikasi pupuk Urea $25 \mathrm{~kg} \mathrm{ha}^{-1}$ dan $\mathrm{KCl} 100 \mathrm{~kg} \mathrm{ha}^{-1}$ dilakukan pada saat tanaman telah berumur $2 \mathrm{MST}$. Pemeliharaan tanaman meliputi penyiraman, pengendalian gulma, dan pengendalian hama dan penyakit. Kedelai dipanen saat tanaman berumur $80 " 82$ hari dengan ciri polong secara merata telah berwarna kuning kecoklatan, batang sudah kering, dan sebagian daun sudah kering atau rontok.

Variabel pengamatan yang diamati pada penelitian ini meliputi tinggi tanaman, jumlah daun tanaman, jumlah cabang total, bintil akar, bobot berangkasan kering yang diamati pada fase vegetatif maksimum, serta jumlah polong bernas, jumlah polong hampa, bobot 100 butir, bobot biji kering per petak dan indeks panen yang diamati setelah masa panen selesai. Dalam satu petak percobaan, jumlah sampel yang diamati sebanyak 10 tanaman.

\section{HASIL DAN PEMBAHASAN}

\section{Pengaruh dosis batuan fosfat alam yang}

diasidulasi limbah cair tahu terhadap

pertumbuhan tanaman kedelai (Glycine max L.)

Berdasarkan hasil analisis ragam, aplikasi dosis BFA yang diasidulasi dengan limbah cair tahu tidak berpengaruh nyata terhadap beberapa komponen pertumbuhan pada fase vegetatif maksimum tanaman kedelai yang meliputi tinggi tanaman, jumlah daun, bintil akar, dan jumlah cabang tetapi berpengaruh nyata terhadap bobot brangkasan kering (Tabel 1). Tidak adanya pengaruh nyata yang terjadi pada beberapa komponen tersebutyaitu diduga dari kandungan unsur hara $\mathrm{P}$ yang masih terjerap di dalam BFA sehingga kandungan P menjadi sedikit diserap oleh tanaman, juga karena sifatnya yang lambat tersedia sehingga dapat berpengaruh pada fase pertumbuhan vegetatif maupun generatif. Kekurangan unsur fosfat dapat menyebabkan tanaman tidak mampu menyerap unsur hara lainnya meskipun jumlah fosfor yang diangkut tanaman sedikit, akan tetapi dalam hal ini efisiensi penggunaan fosfor dari pupuk sangatlah penting untuk tanaman.

PupukBFA yang telah diasidulasi limbah cair tahu 
Tabel 1. Pengaruh Dosis Batuan Fosfat Alam yang Diasidulasi Limbah Cair Tahu terhadap Komponen Pertumbuhan Tanaman Kedelai (Glycine max L.) pada Pengamatan 5 MST

\begin{tabular}{cccccc}
\hline Perlakuan & $\begin{array}{c}\text { Tinggi } \\
\text { Tanaman } \\
(\mathrm{cm})\end{array}$ & $\begin{array}{c}\text { Jumlah Daun } \\
\text { (daun/ } \\
\text { tanaman) }\end{array}$ & $\begin{array}{c}\text { Bintil Akar } \\
\text { (bintil/ } \\
\text { tanam an) }\end{array}$ & $\begin{array}{c}\text { Jumlah } \\
\text { Cabang } \\
\text { (cabang/ } \\
\text { tanaman) }\end{array}$ & $\begin{array}{c}\text { Bobot Brangkasan } \\
\text { Kering } \\
\text { (gram/tanaman) }\end{array}$ \\
\hline $\mathrm{P}_{0}$ & 27,20 & 11 & 1 & 3 & 2,07 \\
$\mathrm{P}_{1}$ & 28,33 & 12 & 1 & 4 & 2,30 \\
$\mathrm{P}_{2}$ & 27,00 & 11 & 0 & 3 & 2,23 \\
$\mathrm{P}_{3}$ & 28,03 & 11 & 1 & 3 & 2,10 \\
$\mathrm{P}_{4}$ & 28,70 & 11 & 1 & 3 & 3,28 \\
$\mathrm{P}_{5}$ & 28,17 & 12 & 1 & 4 & 3,14 \\
$\mathrm{P}_{6}$ & 28,93 & 12 & 1 & 4 & $*$ \\
\hline Uji F & tn & tn & tn & tn & (n \\
\hline
\end{tabular}

Keterangan: $\mathrm{tn}=$ tidak berpengaruh nyata; ${ }^{*}=$ berpengaruh nyata; $\mathrm{tn}=$ tidak berpengaruh nyata;

$\mathrm{P}_{0}=$ Kontrol; $\mathrm{P}_{1}=$ BFA $300 \mathrm{~kg} \mathrm{ha}^{-1}$ tanpa asidulasi; $\mathrm{P}_{2}=$ BFA asidulasi $150 \mathrm{~kg} \mathrm{ha}^{-1} ; \mathrm{P}_{3}=\mathrm{BFA}$

asidulasi $300 \mathrm{~kg} \mathrm{ha}^{-1} ; \mathrm{P}_{4}=\mathrm{BFA}$ asidulasi $450 \mathrm{~kg} \mathrm{ha}^{-1} ; \mathrm{P}_{5}=\mathrm{BFA}$ asidulasi $600 \mathrm{~kg} \mathrm{ha}^{-1} ; \mathrm{P}_{6}=\mathrm{BFA}$ asidulasi $750 \mathrm{~kg} \mathrm{ha}^{-1}$.

Tabel 2. Hasil Analisis Serapan Hara Tanaman

\begin{tabular}{ccccc}
\hline Perlakuan & $\begin{array}{c}\text { Kandungan P } \\
(\%)\end{array}$ & $\begin{array}{c}\text { Serapan P } \\
(\text { gram/tanaman })\end{array}$ & $\begin{array}{c}\text { Kandungan N } \\
(\%)\end{array}$ & $\begin{array}{c}\text { Serapan N } \\
(\text { gram/tana man })\end{array}$ \\
\hline $\mathrm{P}_{0}$ & 0,40 & 0,008 & 3,47 & 0,072 \\
$\mathrm{P}_{1}$ & 0,42 & 0,010 & 3,55 & 0,082 \\
$\mathrm{P}_{2}$ & 0,43 & 0,010 & 3,89 & 0,087 \\
$\mathrm{P}_{3}$ & 0,39 & 0,008 & 3,85 & 0,081 \\
$\mathrm{P}_{4}$ & 0,40 & 0,010 & 3,71 & 0,092 \\
$\mathrm{P}_{5}$ & 0,44 & 0,014 & 3,80 & 0,125 \\
$\mathrm{P}_{6}$ & 0,41 & 0,013 & 4,01 & 0,126 \\
\hline
\end{tabular}

Keterangan : Data Hasil Analisis Laboratorium Ilmu Tanah Fakultas Pertanian Universitas Lampung (2017).

dan diaplikasikan di lahan pada saat sebelum tanam hingga setelah panen masih tersisa banyak di dalam tanah. Bahkan saat pengambilan sampel tanah setelah panen pun masih terlihat butiran pupuk BFA yang masih belum larut seutuhnya. Hal ini diduga karena sifat pupuk P yang sukar untuk larut sehingga $P$ yang diserap oleh kedelai tidak memenuhi kebutuhan. Dalam penelitian Yusuf dkk (2017) menyebutkan bahwa diperhitungkan tidak lebih N, P dan K yang diserap tanaman lewat daun dan lewat tanah tidak lebih dari 10\%, sehinggaunsur $\mathrm{P}$ yang diserap oleh tanaman sangat sedikit. Jika dilihat dari hasil analisis serapan hara yang diperoleh dari penelitian ini (Tabel 2) menunjukkan bahwa tanaman kedelai hanya mampu menyerap P sebesar 0,008 “ 0,014 gram $\operatorname{tanaman}^{-1}$, artinya hanya sedikit jumlah $\mathrm{P}$ yang diserap dikarenakan $\mathrm{P}$ yang masih terjerap di dalam BFA atau belum sepenuhnya tersedia sehingga pertumbuhan tanaman kedelai menjadi ikut terhambat, sedangkan kedelai membutuhkan P dalam jumlah yang relatif banyak karena $\mathrm{P}$ dibutuhkan sepanjang pertumbuhan. Seperti yang dilaporkan dalam penelitian Rosi dkk. (2016), pupuk fosfat super dengan tingkat dosis $360 \mathrm{~kg} \mathrm{ha}^{-1}$ dan $720 \mathrm{~kg} \mathrm{ha}^{-1}$ tidak berpengaruh nyata terhadap tinggi dan jumlah daun 
tanaman kedelai. Hal tersebut disebabkan oleh unsur hara fosfor yang bersifat immobil dan diserap dalam bentuk senyawa anorganik sehingga tidak cepat tersedia di dalam tanah dan diserap oleh tanaman. Dugaan lain yang dapat terjadi yaitu karena adanya fiksasi fosfor yang menyebabkan $\mathrm{P}$ di dalam tanah akan berkurang dikarenakan hara besi, aluminium dan mangan yang mudah larut dalam tanah mineral sangat masam, serta terjadinya reaksi ion $\mathrm{H}_{2} \mathrm{PO}_{4}$ yang mengubah fosfor menjadi tidak larut dan juga tidaktersedia bagi pertumbuhan tanaman.

Selain tinggi tanaman dan jumlah daun, komponen yang tidak dipengaruhi oleh perlakuan ini adalah bintil akar dan jumlah cabang. Penyebab sedikitnya jumlah bintil akar yaitu diduga karena penggunaan lahan sebelumnya yang bukan ditanami oleh tanaman kacang-kacangan serta lahan yang digunakan merupakan lahan kering masam sehingga tidak banyak Rhizobium sp. yang tersedia di dalam tanah. Menurut Harsono dkk (2011) pertumbuhan bakteri Rhizobium di lahan masam menghadapi banyak kendala, di antaranya $\mathrm{pH}$ rendah, kejenuhan $\mathrm{Al}$ tinggi, kandungan Fe dan Mn tinggi. Hal ini berakibat pada tidak terbentuknya bintil akar tanaman kedelai yang berperan dalamproses fiksasi $\mathrm{N}_{2}$ dan berkaitan dengan pembentukan serta aktivitas bintil akar tanaman kedelai. Wicaksono dkk (2015) melaporkan bahwa dengan penambahan Rhizobium pada varietas Wilis memberikan respon yang signifikan terhadap peningkatan serapan nitrogen yang ditandai dengan parameter bintil akar, semakin tinggi jumlah bintil akar efektif, laju fiksasi tanaman juga semakin meningkat.
Dikarenakan sedikitnya jumlah bintil akar yang terbentuk, unsur haraN yang dibutuhkan untuk pertumbuhan vegetatif terutama jumlah cabang menjadi belum mencukupi. Pada hasil analisis serapan hara $\mathrm{N}$ (Tabel 2) menunjukkan bahwa $\mathrm{N}$ yang diserap oleh tanaman sebanyak 0,008 “ 0,014 gram tanaman ${ }^{-1}$, namun kebutuhan $\mathrm{N}$ yang diperlukan secara umum yaitu sekitar 50\% dari $\mathrm{N}$ yang dibutuhkan tanaman berasal dari penambatan oleh Rhizobium sp. serta lahan yang pernah ditanami kedelai pada umumnya mempunyai populasi Rhizobium sp. alami yang tinggi (Salvagiotti dkk., 2008), sedangkan jika dilihat berdasarkan hasil analisis serapan hara di atas menunjukkan bahwa $\mathrm{N}$ yang diserap tanaman kedelai belum memenuhi kebutuhan sebesar 50\% yang seharusnya.

Ketersediaan $\mathrm{P}$ akan menghambat pembentukan bintil akar. Pada analisis yang telah dilakukan (Tabel 3) $\mathrm{pH}$ tanah rata-rata bersifat sangat masam, hal ini berkaitan terhadap ketersediaan $\mathrm{P}$ dalam tanah. Menurut Taufiq(2014) bahwa lahan yang memiliki pH rendah berkaitan dengan daya semat fosfat tinggi yang menyebabkan ketersediaan $\mathrm{P}$ dalam tanah rendah dan efesiensi pemupukan $\mathrm{P}$ menjadi rendah pula. Kekahatan $\mathrm{P}$ ataukecilnya ketersediaan $\mathrm{P}$ akan menghambat pembentukan bintil akar, perkembangan akar, pembentukan polong dan biji sehinggapolongnya sedikit dan ukuran bijinya akan lebih kecil.

Hasil penelitian menunjukkan bahwa pemberian dosis BFA yang diasidulasi limbah cair tahu berpengaruh nyata terhadap bobot brangkasan kering tanaman kedelai (Tabel 4). Hal ini diduga karena unsur P yang terkandung dalam BFA yang sudah sebagian terserap 
Tabel 3. Hasil Analisis Akhir pH dan P-tersedia

\begin{tabular}{ccccc}
\hline Perlakuan & $\mathrm{pH}$ & Kriteria & P-tersedia $(\mathrm{ppm})$ & Kriteria \\
\hline $\mathrm{P}_{0}$ & 4,32 & Sangat Masam & 4,06 & Sangat Rendah \\
$\mathrm{P}_{1}$ & 4,40 & Sangat Masam & 5,81 & Sangat Rendah \\
$\mathrm{P}_{2}$ & 4,37 & Sangat Masam & 4,57 & Sangat Rendah \\
$\mathrm{P}_{3}$ & 4,37 & Sangat Masam & 5,87 & Sangat Rendah \\
$\mathrm{P}_{4}$ & 4,49 & Sangat Masam & 7,02 & Sangat Rendah \\
$\mathrm{P}_{5}$ & 4,58 & Masam & 5,85 & Sangat Rendah \\
$\mathrm{P}_{6}$ & 4,51 & Masam & 6,56 & Sangat Rendah \\
\hline
\end{tabular}

Keterangan: $\mathrm{P}_{0}=$ kontrol; $\mathrm{P}_{1}=300 \mathrm{~kg} \mathrm{ha}^{-1}$ (tanpa asidulasi); $\mathrm{P}_{2}=\mathrm{BFA}$ asidulasi $150 \mathrm{~kg} \mathrm{ha}^{-1} ; \mathrm{P}_{3}=\mathrm{BFA}$ asidulasi $300 \mathrm{~kg} \mathrm{ha}^{-1} ; \mathrm{P}_{4}=$ BFA asidulasi $450 \mathrm{~kg} \mathrm{ha}^{-1} ; \mathrm{P}_{5}=\mathrm{BFA}$ asidulasi $600 \mathrm{~kg} \mathrm{ha}^{-1} ; \mathrm{P}_{6}=\mathrm{BFA}$ asidulasi $750 \mathrm{~kg} \mathrm{ha}^{-1}$. Hasil analisis Laboratorium Fakultas Pertanian UniversitasLampung. Sumber kriteria sifat kimia tanah menurut Balai Penelitian Tanah (2009).

Tabel 4. Uji Lanjut BNT 5\% Pengaruh Dosis Batuan Fosfat Alam yang Diasidulasi Limbah Cair Tahu terhadap Bobot Brangkasan Kering Tanaman Kedelai (Glycine max L.) pada Umur $5 \mathrm{MST}$

\begin{tabular}{cc}
\hline Perlakuan & $\begin{array}{c}\text { Bobot Brangkasan Kering } \\
\left(\text { gram tanaman }^{-1}\right)\end{array}$ \\
\hline $\mathrm{P}_{0}($ kontrol) & $2,07 \mathrm{~b}$ \\
$\mathrm{P}_{1}\left(\right.$ BFA 300 kg ha $\left.^{-1}\right)$ & $2,30 \mathrm{~b}$ \\
$\mathrm{P}_{2}\left(\right.$ BFA asidulasi $\left.150 \mathrm{~kg} \mathrm{ha}^{-1}\right)$ & $2,23 \mathrm{~b}$ \\
$\mathrm{P}_{3}\left(\right.$ BFA asidulasi $\left.300 \mathrm{~kg} \mathrm{ha}^{-1}\right)$ & $2,10 \mathrm{~b}$ \\
$\mathrm{P}_{4}\left(\right.$ BFA asidulasi $\left.450 \mathrm{~kg} \mathrm{ha}^{-1}\right)$ & $2,47 \mathrm{~b}$ \\
$\mathrm{P}_{5}\left(\right.$ BFA asidulasi $\left.600 \mathrm{~kg} \mathrm{ha}^{-1}\right)$ & $3,28 \mathrm{a}$ \\
$\mathrm{P}_{6}\left(\right.$ BFA asidulasi $\left.750 \mathrm{~kg} \mathrm{ha}^{-1}\right)$ & $3,14 \mathrm{a}$ \\
\hline BNT 5\% & 0,55 \\
\hline
\end{tabular}

Keterangan: Angka-angka yang diikuti dengan huruf yang sama pada setiap kolom menunjukkan pengaruh yang tidak berbeda nyata berdasarkan pengujian BNT $5 \%$.

dimanfaatkan oleh tanaman kedelai dalam pembentukan energi, sehingga dengan peningkatan pemberian P maka akan meningkatkan laju fotosintesis. Menurut Rahmah (2014) dalam Haryadi dkk (2015) adanya peningkatan biomassa dikarenakan tanaman menyerap air dan hara lebih banyak unsur hara. Dalam tanaman, P merupakan unsur penting penyusun adenosin triphosphate (ATP) yang secara langsung berperan dalam proses penyimpanan dan transfer energi yang terkait dalam proses metabolisme tanaman (Dobermann dan Fairhurst, 2000). Senyawa P untuk transfer energi terdapat dalam bentuk ADP (Adenosin Difosfat), ATP(Adenosin Trifosfat) dan fosfor organik sehingga unsur P mendukung metabolisme tanaman jika dalam keadaan yang cukup. Jika terganggunya metabolisme tanaman maka pertumbuhan dan produksi tanaman akan terganggu juga.

\section{Pengaruh dosis batuan fosfat alam yang}

diasidulasi limbah cair tahu terhadap produksi tanaman kedelai (Glycine max L.)

Berdasarkan analisis pada komponen hasil produksi (Tabel 5) menunjukkan bahwa pemberian 
Tabel 5. Pengaruh Dosis Batuan Fosfat Alam yang Diasidulasi Limbah Cair Tahu terhadap

Komponen Produksi Tanaman Kedelai (Glycine max L.)

\begin{tabular}{cccccc}
\hline Perlakuan & $\begin{array}{c}\text { Bobot Biji } \\
\text { Kering Per } \\
\text { Petak } \\
\text { (gram/tanaman) }\end{array}$ & $\begin{array}{c}\text { Jumlah } \\
\text { Polong } \\
\text { Bernas (buah/ } \\
\text { tanaman) }\end{array}$ & $\begin{array}{c}\text { Jumlah } \\
\text { Polong } \\
\text { Hampa } \\
\text { buah/ } \\
\text { tanaman) }\end{array}$ & $\begin{array}{c}\text { Bobot } \\
100 \text { Butir } \\
\text { (gram/ } / \\
\text { tanaman) }\end{array}$ & $\begin{array}{c}\text { Indeks Panen } \\
\left(90 \text { tan } / 9 \mathrm{~m}^{2}\right)\end{array}$ \\
\hline $\mathrm{P}_{0}$ & 191,57 & 20 & 1 & 14,39 & 0,32 \\
$\mathrm{P}_{1}$ & 246,44 & 21 & 1 & 15,04 & 0,32 \\
$\mathrm{P}_{2}$ & 190,27 & 19 & 1 & 14,30 & 0,25 \\
$\mathrm{P}_{3}$ & 194,41 & 16 & 1 & 14,87 & 0,28 \\
$\mathrm{P}_{4}$ & 225,49 & 19 & 1 & 14,28 & 0,34 \\
$\mathrm{P}_{5}$ & 236,76 & 21 & 2 & 15,18 & 0,33 \\
$\mathrm{P}_{6}$ & 266,67 & 25 & 1 & 15,04 & 0,33 \\
\hline Uji F & tn & tn & tn & tn & tn \\
\hline
\end{tabular}

Keterangan: tn $=$ tidak berpengaruh nyata; $\mathrm{P}_{0}=$ Kontrol; $\mathrm{P}_{1}=\mathrm{BFA} 300 \mathrm{~kg} \mathrm{ha}^{-1}$ tanpa asidulasi; $\mathrm{P}_{2}=\mathrm{BFA}$ asidulasi $150 \mathrm{~kg} \mathrm{ha}^{-1} ; \mathrm{P}_{3}=$ BFA asidulasi $300 \mathrm{~kg} \mathrm{ha}^{-1} ; \mathrm{P}_{4}=\mathrm{BFA}$ asidulasi $450 \mathrm{~kg} \mathrm{ha}^{-1} ; \mathrm{P}_{5}=$ BFA asidulasi $600 \mathrm{~kg} \mathrm{ha}^{-1} ; \mathrm{P}_{6}=\mathrm{BFA}$ asidulasi $750 \mathrm{~kg} \mathrm{ha}^{-1}$.

dosis BFAyang diasidulasi dengan limbah cair tahu tidak memberikan pengaruh nyata terhadap bobot biji kering perpetak, jumlah polong bernas, jumlah polong hampa, bobot 100 butir maupun indeks panen. Hal ini disebabkan akibat dari P-tersedia yang terdapat di dalam tanah berjumlah sedikit dan masih tergolong ke dalam kriteria sangat rendah, sehingga unsur hara $\mathrm{P}$ yang seharusnya dibutuhkan oleh tanaman belum tercukupi hingga tidak berpengaruh pada hasil produksi.

Potensi hasil kedelai varietas Argomulyo adalah 1,5-2,0 ton ha ${ }^{-1}$, sedangkan hasil pada penelitian ini diperoleh 0,0143 ton $\mathrm{ha}^{-1}$ masih jauh dari potensi hasil kedelai yang seharusnya. Hal ini diduga karena faktor cuaca, karena dalam pelaksanaannya dilakukan pada musim kemarau, sehingga tanaman kedelai kekurangan asupan air yang cukup. Hal ini dapat dilihat dari jumlah curah hujan rata-rata pada saat penelitian berlangsung hanya sebanyak $44-51,8 \mathrm{~mm} / \mathrm{bulan}$, sedangkan curah hujan rata-rata yang dibutuhkan oleh tanaman kedelai adalah sebanyak $150-200 \mathrm{~mm} /$ bulan. Artinya bahwa jumlah kebutuhan air yang dibutuhkan oleh tanaman kedelai masih jauh dari kata cukup, sehingga untuk proses tanaman menyerap nutrisi-nutrisi di dalam tanah masih belum terpenuhi secara optimal yang mengakibatkan hasil produksi kedelai rendah. Begitu pula pada penelitian Arianti (2018), walaupun dengan pemberian dosis BFA sebesar $800 \mathrm{~kg} \mathrm{ha}^{-1}$ sudah mampu memberikan hasil terbaik untuk tanaman jagung pada komponen produksi berupa bobot biji kering per petak, tetapi jumlah produksi yang dihasilkan masih jauh dari potensi hasil yang seharusnya.

Faktor lain diduga karena limbah cair tahu yang belum mampu membantumelarutkan P dari BFAdalam proses asidulasi. Karena jika dilihat dari hasil analisis $\mathrm{pH}$ yang terdapat di dalam limbah cair tahu (Tabel 3), pH limbah cair tahu hanya 3,76 sehingga meskipun sudah dilakukan asidulasi tetapi asam yang diberikan 
Tabel 6. Uji Korelasi Beberapa Sifat Kimia Tanah Akhir Panen dengan Tanaman Kedelai

\begin{tabular}{cccc}
\hline & \multicolumn{3}{c}{ Koefisien korelasi (r) } \\
\cline { 2 - 4 } Variabel & $\begin{array}{c}\text { Bobot Brangkasan } \\
\text { Kering } \\
(\text { gram/tanam })\end{array}$ & $\begin{array}{c}\text { Bobot 100 Butir } \\
(\text { gram/tanaman) }\end{array}$ & $\begin{array}{c}\text { Bobot Biji Kering per } \\
\text { Petak } \\
(\text { gram/tanaman })\end{array}$ \\
\hline pH & $0,42^{\text {tn }}$ & $0,06^{\text {tn }}$ & $0,16^{\text {tn }}$ \\
P-tersedia & $0,46^{*}$ & $0,19^{\text {tn }}$ & $0,24^{\text {n }}$ \\
Serapan P & $0,97^{*}$ & $0,62^{*}$ & $0,73^{*}$ \\
Serapan N & $0,98^{*}$ & $0,65^{*}$ & $0,72^{*}$
\end{tabular}

Keterangan : * = berkorelasi nyata pada taraf 5\%; tn = berkorelasi tidak nyata pada taraf $5 \%$; n data untuk $\mathrm{pH}$ dan P-tersedia $=21$ sampel; $\mathrm{n}$ data untuk Serapan P dan Serapan N $=7$ sampel.

pada BFA masih belum mampu melarutkan $\mathrm{P}$ didalamnya. Berbeda pada penelitian Aini dkk(2013), asidulasi BFA tidak hanya diberi asam berupa limbah cair tahu tetapi dikombinasikan dengan asam sulfat. Karena untuk melarutkan $\mathrm{P}$ dari batuan fosfat harus dilakukan dengan cara asidulasi menggunakan senyawa asam seperti asam sulfat $1 N$ yang memiliki pH 1 .

\section{Uji korelasi beberapa sifat kimia tanah dengan} tanaman kedelai

Berdasarkan hasil uji korelasi (Tabel 6), bahwa tidak terdapat korelasi pada kandungan $\mathrm{pH}$ terhadap beberapa komponen tanaman kedelai. Akan tetapi berbeda halnya dengan P-tersedia, serapan P, dan serapan $\mathrm{N}$, ketiga sifat kimia tanah tersebut memiliki korelasi terhadap beberapa komponen tanaman kedelai yang di amati dalam penelitian ini.

Jika dilihat, bobot brangkasan kering meningkat seiring dengan $\mathrm{P}$ yang tersedia di dalam tanah, serta semakin tinggi $\mathrm{P}$ dan $\mathrm{N}$ yang diserap oleh tanaman maka bobot berangksan kering, bobot 100 butir dan bobot biji kering per petak juga akan meningkat. Hubungan kadar fosfor dan nitrogen berbanding positif dengan bobot brangkasan kering dan bobot 100 butir maupun bobot biji kering per petak yang dihasilkan. Hal tersebut memperlihatkan bahwa kadar fosfor dan nitrogen dalam tanaman berhubungan erat dengan bobot brangkasan kering tanaman yang dihasilkan atau biomasaa tanaman yang memengaruhi tingginya serapan $\mathrm{N}$ dan $\mathrm{P}$ tanaman.

Perakaran yang lebih berkembang akan memungkinkan bagi penyerapan hara yang lebih optimal. Sebagian besar unsur hara $\mathrm{N}$ dan $\mathrm{P}$ dibawa akar ke titik tumbuh, batang, daun, dan bunga, lalu dialihkan ke biji. Dengan demikian, unsur hara $\mathrm{N}$ dan P terangkut dari tanah melalui biji saat panen yangmengakibatkan peningkatan produksi. Sebagaimana dijelaskan oleh Yusuf dkk (2017) bahwatanaman kedelai memerlukan unsur $\mathrm{P}$ dalam setiap masa pertumbuhannya, dan serapan unsur $\mathrm{P}$ oleh tanaman juga dipengaruhi oleh adanya unsur N. Unsur $\mathrm{N}$ secara langsung berperan dalam pembentukan protein, memacu pertumbuhan tanaman secara umum terutama pada fase vegetatif, berperan dalam pembentukan klorofil, asam amino, lemak enzim dan persenyawaan lain sehingga unsur $\mathrm{N}$ dan $\mathrm{P}$ terusmenerus diserap tanaman sampai mendekati matang. 


\section{KESIMPULAN}

Kesimpulan yang dapat ditarik pada penelitian ini adalah bahwa pemberian dosis batuan fosfat alam (BFA) yang telah diasidulasi dengan menggunakan limbah cair tahu dapat meningkatkan bobot brangkasan kering dibandingkan dengan yang tidak diasidulasi dengan limbah cair tahu dan mampu memberikan hasil terbaik pada bobot brangkasan kering dengan dosis600 kg ha-1 sebesar 3,28 gram tanaman ${ }^{-1}$ dan dengan dosis $750 \mathrm{~kg} \mathrm{ha}^{-1}$ sebesar 3,14 gram tanaman${ }^{1}$, serta untuk hasil produksi diperoleh sebanyak0,0143 ton ha ${ }^{-1}$ meskipun masih jauh dari potensi hasil kedelai yang seharusnya.

\section{DAFTAR PUSTAKA}

Aini, S.N., A. Niswati, Sarno, dan S. Yusnaini. 2013. Peningkatan $\mathrm{P}$ larut dari batuan fosfat dengan campuran limbah cair tahu dan asam sulfat. Seminar NasionalSains \&Teknologi $V$. Lembaga Penelitian Universitas Lampung. $848-860 \mathrm{Hlm}$.

Arianti, D. 2018. Pengaruh dosis batuan fosfat yang diasidulasi limbah cair tapioka terhadap pertumbuhan dan produksi jagung (Zea mays L.) [Skripsi]. $29 \mathrm{Hlm}$.

Dobermann, A. dan T. Faihurst. 2000. Rice, Nutrient Disorders and Nutrient Management. Manila: IRRI and Potash \& Phosphate Institute of Canada.

Harsono, A., Prihastuti, dan Subandi. 2011. Efektivitas multi-isolat rhizobium dalam pengembangan kedelai di lahan kering masam. Iptek Tanaman Pangan. 6 (1) : $57-75$.
Haryadi, D., H. Yetti, dan S. Yoseva. 2015. Pengaruh pemberian beberapa jenis pupuk terhadap pertumbuhan dan produksi tanaman kailan (Brassica alboglabra L.)

Kementan. 2019. Data Lima Tahun Terakhir: Sub-sektor Tanaman Pangan. http:// w w w.pertanian.go.id/home/ ?show $=$ page $\&$ act $=$ view $\&$ id=61. Diakses pada tanggal 10 Januari 2019 pukul 20:21 WIB.

Rosi, A., A. Niswati, S. Yusnaini, dan A. K. Salam. 2016. Penentuan dosis dan ukuran butir pupuk fosfat super terbaik untuk mendukung pertumbuhan dan serapan $\mathrm{P}$ tanaman kedelai (Glycine max [L.] Merril). J. Agrotek Tropika. 4 (1): 70 “ 74.

Salvagiotti, F., K.G. Cassman, J.E. Specht, D.T. Walters, A. Weiss and A. Dobermann. 2008. Nitrogen uptake, fixation and response to Fertilizer N in soybeans: A review. Field Crops Res. 108 (1) : $1-13$.

Taufiq, A. 2014. Identifikasi Masalah Keharaan Tanaman Kedelai. Balai Penelitian Tanaman Aneka Kacang dan Umbi. Malang.

Wicaksono, M., H. Hanum, dan D. Elfianti. 2015. Efisiensi serapan nitrogen tiga varietas kedelai dengan pemupukan nitrogen dan penambahan rhizobium pada tanah dengan status hara $\mathrm{N}$ rendah. J. Pertanian Tropik. 2 (2) : 140 147.

Yusuf, F., J. Hadie, dan M. F. H. Yusran. 2017. Respon tanaman kedelai terhadap serapan hara NPK pupuk daun yang diberikan melalui akar dan daun pada tanah gambut dan podsolik. J.Daun. 4 (1) : $17-28$. 